\title{
Prophecy as History: A New Study of the Prophecies of Merlin Silvester
}

\author{
Victoria Flood ${ }^{1}$
}

Published online: 14 May 2018

(C) The Author(s) 2018

\begin{abstract}
The Prophecies of Merlin Silvester is the name given to a thirteenthcentury collection of Latin prophecies, which has long been, problematically, understood to be a translation from an earlier Welsh text. This article offers a new study of early manuscripts containing the Prophecies, and considers their place in English political culture. It argues that the Prophecies were composed in England during the reign of John, articulating anxieties about threats from France and domestic misrule, situated in a long historical view. In this respect, the Prophecies are revealed as a mode of commentary on English history.
\end{abstract}

Keywords Merlin · Prophecy · Gerald of Wales · Geoffrey of Monmouth

This article presents a new study of the Prophecies of Merlin Silvester (also known as the Prophecy of the Eagle), a collection of prophetic texts incorporating a retrospective of English history from the Norman Conquest to the reign of John. ${ }^{1}$ They are found in a relatively consistent form in manuscripts produced between the thirteenth and seventeenth centuries, and enjoyed an enthusiastic reception in both England and Wales. Although described by their most recent translators, Anne

\footnotetext{
1 Parry prints a Latin version of the text, based on London, British Library, Cotton Faustina A. viii, British Library, Arundel 409, and British Library, Cotton Nero, D. viii. (Parry 1937, 225-26). An earlier edition of the text appears in Schulz (1854, 463-65), based on Leiden, University Library, VLF 77. An English translation of the version of the prophecy in Leningrad, Saltykov-Sheedrin State Public Library, F. 4. 76 is printed in Sutton and Visser-Fuchs (1989).
}

Victoria Flood

v.flood@bham.ac.uk

1 Department of English Literature, Arts Building, University of Birmingham,

Birmingham B15 2TT, UK 
Sutton and Livia Visser-Fuchs, as 'confused, confusing and obscure', the popularity of the collection was long-lived, and by the reign of Richard III, as the two note, it was 'part of almost every educated person's library', and the object of political interpretation well into the $1600 \mathrm{~s}$ (Sutton and Visser-Fuchs 1990, 351; see also Sutton and Visser-Fuchs 1989, 1992). Critics have accounted for the collection's supposed obscurity by its long assumed status as a Latin translation from a Welsh bardic original (Sutton and Visser-Fuchs 1990, 294; McCauley 1993). This argument takes its force from correspondences between one component prophecy of the collection and the prophecies of Merlin Silvester, which Gerald of Wales quotes in his account of the late twelfth-century conquest of Ireland, the Expugnatio Hibernica (c. 1189) (Scott and Martin 1978). The collection has been understood to be representative of material found in Gerald's reputed Welsh source book, a book of the prophecies of Merlin Silvester, which in the Expugnatio, and his later Itinerarium Cambriae (c. 1194), Gerald claimed to have discovered at a monastery in Nefyn, in North Wales (Scott and Martin 1978, 57; Thorpe 1978, 183). Gerald appears to have once intended a translation of the Welsh book to form the third book of his Expugnatio, although this was never to materialise (Scott and Martin 1978, 253-57; Thorpe 1978, 183). The precise nature of Gerald's Welsh book remains uncertain, but the Prophecies of Merlin Silvester, as the collection survives, certainly post-date Gerald, and must be understood not as a Latin translation from a common Welsh source, but an important piece of Giraldian reception history, in an English political context. What is more, Gerald's prophecies themselves owe far more to prophetic strategies borrowed from Geoffrey of Monmouth's Prophetiae Merlini (c. 1138) than to any putative Welsh source. Although Geoffrey's own debt to earlier Welsh prophetic material is well remarked upon, the Prophetiae are no means an unmediated representative of a Welsh prophetic tradition (see, most recently, Flood 2016, 21-43). Rather, they stand as the origin point of a new Latinate discourse of political prophecy produced in England, to which tradition the Prophecies of Merlin Silvester also belongs.

\section{The Collection and Its Early Reception History}

The Prophecies of Merlin Silvester survive in a number of early manuscript witnesses from the thirteenth and fourteenth centuries, nearly all of which were produced in monastic or ecclesiastical contexts (the early manuscripts are itemised in Table 1). ${ }^{2}$ This provides the most plausible conditions for its original production. The political interests and sympathies of the collection (discussed below) suggest that it was produced in England. It was received with particular enthusiasm in the south and the Midlands, and may well have originated somewhere in this wide region.

\footnotetext{
${ }^{2}$ This survey is by no means exhaustive, although it aims to give an account of all the early (thirteenthand fourteenth-century) manuscripts, held at libraries in the United Kingdom, noted in Sutton and VisserFuchs (1989).
} 
Table 1 Early witnesses of the Prophecies of Merlin Silvester

\begin{tabular}{|c|c|c|c|}
\hline Manuscript & $\begin{array}{l}\text { Date of inclusion of } \\
\text { text }\end{array}$ & $\begin{array}{l}\text { Medieval institutional } \\
\text { association }\end{array}$ & $\begin{array}{l}\text { Contents and } \\
\text { relationships of text }\end{array}$ \\
\hline $\begin{array}{l}\text { Bodleian Library, Digby } \\
28 \text { (fols 168r-169r) } \\
\text { (Macray 1883, 24-25; } \\
\text { Ker } 1964,157 \text { ) }\end{array}$ & $\begin{array}{l}\text { Early fourteenth } \\
\text { century }\end{array}$ & $\begin{array}{l}\text { Canterbury, Christ } \\
\text { Church }\end{array}$ & $\begin{array}{l}\text { 'Prophecia siluestris } \\
\text { merlini'; three } \\
\text { component prophecies. } \\
\text { Follows Prophetiae } \\
\text { Merlini }\end{array}$ \\
\hline $\begin{array}{l}\text { British Library, } \\
\text { Additional 40007 (fol. } \\
\text { 41v) (Ker 1964, 140) }\end{array}$ & $\begin{array}{l}\text { Early thirteenth } \\
\text { century }\end{array}$ & $\begin{array}{l}\text { Manuscript contains } \\
\text { pressmark of St Mary's } \\
\text { Abbey, York }\end{array}$ & $\begin{array}{l}\text { 'Prophecia merlini } \\
\text { siluestris'; 'Arbor } \\
\text { fertilis' only }\end{array}$ \\
\hline $\begin{array}{l}\text { British Library, Arundel } \\
409 \text { (fols 23r-24r) } \\
\text { (Ward 1883, I, 233; } \\
\text { British Museum 1834, } \\
\text { I, 118; Crick 1989, } \\
\text { 140-42) }\end{array}$ & Thirteenth century & $\begin{array}{l}\text { MS contains copy of } \\
1295 \text { deed, concerning } \\
\text { church of 'Kyrkun' in } \\
\text { diocese of 'Candida } \\
\text { Case'-Whithorn, } \\
\text { Galloway }\end{array}$ & $\begin{array}{l}\text { 'Prophecia merlini } \\
\text { silvestris'; 'Sicut } \\
\text { rubeum' and 'Mortuo } \\
\text { leone'. Follows } \\
\text { Historia }\end{array}$ \\
\hline $\begin{array}{l}\text { British Library, Cotton } \\
\text { Faustina A. viii (fols } \\
\text { 115r-116r) (Planta } \\
\text { 1802, 603-04; Ward } \\
\text { 1883, I, 292-95; Ker } \\
\text { 1964, 143) }\end{array}$ & $\begin{array}{l}\text { Mid-thirteenth } \\
\text { century }\end{array}$ & $\begin{array}{l}\text { MS contains annals of } \\
\text { Priory of St Mary } \\
\text { Overy, Southwark }\end{array}$ & $\begin{array}{l}\text { 'Prophetia merlini } \\
\text { silvestris'; three } \\
\text { component prophecies, } \\
\text { separately demarcated. } \\
\text { Follows Prophetiae } \\
\text { Merlini }\end{array}$ \\
\hline
\end{tabular}

British Library, Cotton Nero A. iv (fols 63r65r) (Planta 1802, 202; Ward 1883, I, 297-98; Given-Wilson 2003, 79)

\section{British Library, Cotton Early thirteenth Nero D. viii (fol. 175r) \\ century} (Planta 1802, 238-39; Ward 1883, I, 113-14; Crick 1989, 149-52)

British Library, Cotton Tiberius A. ix (fol. 2rfol. 3v) (Planta 1802, 33-34; Ker 1964, 141)

British Library, Harley 1717 (fol. 250v) (Ward 1883, I, 312)

British Library, Royal 5. F. XV (fol. 3v) (Ward 1883, I, 313; Warner and Gilson 1921, I, 125-26; Ker 1964, 146)
MS contains Chronicle of Colchester Abbey

Fourteenth century

MS contains Chronicle of St Augustine's, Canterbury. Has also been associated with Osney Abbey (Oxfordshire)

Thirteenth century

MS contains fifteenthcentury ascription from church of St John of Beverley (Yorkshire)

Mid-late thirteenth century
Note concerning payment between two brothers, one of Ramsey Abbey, Huntington, and names of monks from the house appear in marginal annotations
'Prophecia merlini siluestris'; three component prophecies. MS also contains Prophetiae Merlini

Top of page cut off, so no ascription visible. Remainder of 'Sicut rubeum' and 'Mortuo leone' run continuously

'Mortuo leone' only. No ascription 
Table 1 continued

\begin{tabular}{|c|c|c|c|}
\hline Manuscript & $\begin{array}{l}\text { Date of inclusion of } \\
\text { text }\end{array}$ & $\begin{array}{l}\text { Medieval institutional } \\
\text { association }\end{array}$ & $\begin{array}{l}\text { Contents and } \\
\text { relationships of text }\end{array}$ \\
\hline $\begin{array}{l}\text { British Library, Royal } 8 . \\
\text { D. III (fol. 163r, col. 2) } \\
\text { (Ward 1883, I, 297; } \\
\text { Warner and Gilson } \\
\text { 1921, I, 240-42; Ker } \\
\text { 1964, 147) }\end{array}$ & $\begin{array}{l}\text { Mid-late thirteenth } \\
\text { century }\end{array}$ & $\begin{array}{l}\text { Notes on flyleaves refer } \\
\text { to Ramsey Abbey, } \\
\text { Huntingdon }\end{array}$ & $\begin{array}{l}\text { 'Mortuo leone' only. No } \\
\text { ascription. Follows } \\
\text { Prophetiae Merlini }\end{array}$ \\
\hline $\begin{array}{l}\text { British Library, Royal } 15 . \\
\text { C. XVI (fols 183v, col. } \\
\text { 2- 184r) (Ward 1883, I, } \\
\text { 44-46, 239, 313; } \\
\text { Warner and Gilson } \\
\text { 1921, II, 170; Ker } \\
\text { 1964, 149; Crick 1989, } \\
\text { 188-89) }\end{array}$ & $\begin{array}{l}\text { Late fourteenth } \\
\text { century or early } \\
\text { fifteenth }\end{array}$ & $\begin{array}{l}\text { Donated to the Hospital } \\
\text { of St Thomas of Acon, } \\
\text { London, by 'Henrici } \\
\text { Spycer canonici ex } \\
\text { Wyndesor' (1402-37) }\end{array}$ & $\begin{array}{l}\text { 'Prophecia aquile'; three } \\
\text { component prophecies. } \\
\text { Follows Historia }\end{array}$ \\
\hline $\begin{array}{l}\text { Cambridge, Corpus } \\
\text { Christi College } 313 \\
\text { (fols 73r-73v) (James } \\
\text { 1911-12, I, 114-17) }\end{array}$ & $\begin{array}{l}\text { Early-mid } \\
\text { thirteenth-century }\end{array}$ & Unknown & $\begin{array}{l}\text { 'Prophecia merlini } \\
\text { siluestris'; three } \\
\text { component prophecies. } \\
\text { Follows Prophetiae } \\
\text { Merlini }\end{array}$ \\
\hline $\begin{array}{l}\text { Cambridge, Corpus } \\
\text { Christi College } 404 \\
\text { (fols 96v-98r) (James } \\
\text { 1911-12, I, 269-77; } \\
\text { Ker 1964, 130) }\end{array}$ & $\begin{array}{l}\text { Compiled between } \\
1350 \text { s and } 1381 . \\
\text { Prophetic } \\
\text { collection of } \\
\text { Henry of } \\
\text { Kirkstede. }\end{array}$ & $\begin{array}{l}\text { Produced at Bury St } \\
\text { Edmunds }\end{array}$ & $\begin{array}{l}\text { No ascription; three } \\
\text { component prophecies }\end{array}$ \\
\hline $\begin{array}{l}\text { Cambridge, St John's } \\
\text { College G. } 16 \text { (112v- } \\
\text { 113r) (James 1913, } \\
\text { 217-22; Crick 1989, } \\
\text { 51-55) }\end{array}$ & Fourteenth century & $\begin{array}{l}\text { In ownership of Exeter } \\
\text { Cathedral by } 1493, \\
\text { although James has } \\
\text { suggested it looks like a } \\
\text { Peterborough } \\
\text { production }\end{array}$ & $\begin{array}{l}\text { 'Hic incipit prophecia } \\
\text { aquile schestonie'; } \\
\text { three component } \\
\text { prophecies. Follows } \\
\text { Historia }\end{array}$ \\
\hline $\begin{array}{l}\text { Cambridge University } \\
\text { Library, Ff. i. } 27 \text { (fols } \\
\text { 112r-112v) (Ker 1964, } \\
\text { 127) }\end{array}$ & $\begin{array}{l}\text { Early fourteenth } \\
\text { century }\end{array}$ & $\begin{array}{l}\text { Two MSS bound together } \\
\text { - thirteenth-century } \\
\text { from Salley Abbey, } \\
\text { Yorkshire, and early } \\
\text { fourteenth-century } \\
\text { from Bury. The } \\
\text { Prophecies of Merlin } \\
\text { Silvester appear in the } \\
\text { latter, and may well } \\
\text { have been the source } \\
\text { used by Henry of } \\
\text { Kirkstede for the } \\
\text { prophecy in CCCC } 404\end{array}$ & $\begin{array}{l}\text { No ascription; three } \\
\text { component prophecies. } \\
\text { MS also contains } \\
\text { Prophetiae Merlini, and } \\
\text { works by Gerald of } \\
\text { Wales, including } \\
\text { Expugnatio }\end{array}$ \\
\hline $\begin{array}{l}\text { London, Lambeth Palace } \\
144 \text { (fols 33v-34r) (Ker } \\
\text { 1964, 150) }\end{array}$ & ?Thirteenth century & $\begin{array}{l}\text { St Augustine's } \\
\text { Canterbury }\end{array}$ & $\begin{array}{l}\text { 'Prophecia merlini } \\
\text { siluestris'. 'Sicut } \\
\text { rubeum' and 'Mortuo } \\
\text { leone' only. Preceded } \\
\text { by double ascription to } \\
\text { Merlin Silvester and } \\
\text { Edward }\end{array}$ \\
\hline
\end{tabular}


Table 1 continued

\begin{tabular}{llll}
\hline Manuscript & $\begin{array}{l}\text { Date of inclusion of } \\
\text { text }\end{array}$ & $\begin{array}{l}\text { Medieval institutional } \\
\text { association }\end{array}$ & $\begin{array}{l}\text { Contents and } \\
\text { relationships of text }\end{array}$ \\
\hline $\begin{array}{c}\text { London, Lambeth Palace } \\
527 \text { (fols 44r-45v) }\end{array}$ & Fourteenth century & $\begin{array}{c}\text { ?Ludlow. Same scribe as } \\
\text { BL, Cotton Nero A. iv } \\
\text { (identical illustrative } \\
\text { glosses on copy of } \\
\text { Prophetiae Merlini) }\end{array}$ & $\begin{array}{l}\text { 'Prophecia aquile', } \\
\text { ascribed to the eagle of } \\
\text { Shaftsbury. Omits }\end{array}$ \\
& & $\begin{array}{l}\text { 'Arbor fertilis'. } \\
\text { contains Prophetiae } \\
\text { Merlini }\end{array}$ \\
\hline
\end{tabular}

The textual elements included in and omitted from manuscript witnesses vary, but the collection appears most fully as a sequence of three prophecies, most commonly divided into three separate texts. The first is 'Arbor fertilis', a dream of Edward the Confessor concerning the Norman invasion and the later succession of Henry II, adapted from the 1163 Vita Edwardi of Ailred of Riveaulx (for discussion of the original dream, see Walker 1984, 46; Thomas 2003, 56-57; Ashe 2007, 3133). This part appears both with and without an additional sequence long ago identified (perhaps erroneously) as a legal note (Ward 1883-1910, I, 293). The note is difficult to reconstruct, but appears to refer to the division of land. The second component prophecy is 'Sicut rubeum draconem', a king list from William I to John. This part incorporates a late twelfth-century English vernacular prophecy concerning English campaigns in Apulia and Ireland, known as the 'Here Prophecy' (Hales 1893, 55-61; Schofield 1906, 368; Wells 1926, 221; Robbins 1975, 1529). The final text of the collection is 'Mortuo leone', an account of the reign of Stephen and the succession of Henry II. 'Mortuo leone' is omitted from a number of witnesses, and also saw independent circulation.

This type of prophetic collection, combining texts of different dates and origins, circulating as a set of related prophecies, is not unique in medieval English prophetic manuscripts. We might think, for example, of the Verses of Gildas, which first appear together in the fourteenth-century London, British Library, Arundel 57. This is a collection of well-known prophecies concerning the international campaigns of a king of England, of separate origin but presented as part of a coherent sequence (Phillips 1986, 194-95). Questions of date and original authorship in such a context are inevitably difficult, but in the case of the Prophecies of Merlin Silvester, we might most intelligibly understand the principal point of new composition to be 'Sicut rubeum', which was added to 'Arbor fertilis' to create a continuous king list and political commentary from the death of Edward the Confessor to the reign of John. This was combined with 'Mortuo leone' which, presumably through its thematic parity with 'Arbor fertilis' was understood to be a meaningful coda. The impetus for the complete project, I argue, belongs to the reign of John, and, as internal allusions suggest, may have been completed contemporary with anxieties about the King of France's threatened invasion of England in the early-mid 1210s. The earliest attempt to date the Prophecies was made by Rupert Taylor, who argued that the collection contains no genuine allusions later than the 
reign of Henry II, and that all references to Henry's sons were later interpolations (Taylor 1911, 21-23). In the absence of (as far as I am aware) any witnesses of the Prophecies without this material, this claim is without foundation.

Although produced in England, the collection circulated throughout Britain. One early witness, Arundel 409, was probably copied at Whithorn, in Galloway; and a commentary on the prophecy which integrated Welsh names and historical points of reference is preserved in two manuscripts: British Library, Cotton Nero A. iv and London, Lambeth Palace 527, both the work of a single scribe associated with Ludlow. It was also incorporated in some versions of the Brut $y$ brenhinedd (translations from Geoffrey of Monmouth's Historia Regum Britanniae), including the fourteenth-century British Library, Cotton Cleopatra B. v, produced at Valle Crucis Abbey, a Cistercian house in north Wales (Parry 1937). Often understood to be one of the most individual of the Welsh brutiau, the Cleopatra Brut incorporates native Welsh material, additional Latin material, and, it has been suggested, elements borrowed from the English and French vernacular translations of the Historia by Lazamon and Wace. It has been regarded as a 'conscious, scholarly, compilation' (Parry 1930, 430 n1; Roberts 2008, 111). Among the compiler's Latin sources we must count the Prophecies of Merlin Silvester, for the Welsh-language version inserted here appears to have been translated directly from the Latin collection, with only a few small emendations, although it omits 'Arbor fertilis' altogether. The Welsh translation was, for a while, thought by scholars of the Prophecies of Merlin Silvester to be representative of Gerald's lost prophetic book, although in the context of studies of the Welsh brutiau, its status as a translation from an Anglo-Latin text is relatively well accepted. Like other prophecies translated from Latin, French or English, the Welsh version of the collection stands apart from the verse compositions of the native Welsh prophetic tradition, and in this case retains the prose form of the Latin original.

Like other borrowed or translated prophetic texts, material from the Prophecies also circulated independently in Wales, entitled 'Prophetia Aquile' or, in Welsh translation, 'Proffwydoliaeth yr Eryr' (an ascription discussed further below), in manuscripts which also contain traditional Welsh political prophecy, including the late fourteenth-century Red Book of Hergest (Oxford, Jesus College 111) (Evans 1891; Jones 2013, 242). However, from the perspective of Welsh literary history, its main interest lies in its place in the history of translations from Latin into Welsh in the production of Welsh historical prose writing, specifically the brutiau. Like Geoffrey of Monmouth's Prophetiae Merlini, the Prophecies were added to, or omitted from, different versions of the Brut, and it has been suggested that their treatment might be one way of tracing the relationship between surviving brutiau (Reiss 1968-69, 102; for a revised appraisal of this, see Roberts 1971, xxvi-xxvii). It also appears to have been a natural accompaniment to the Prophetiae outside the Brut tradition. The two prophecies both appear as stand-alone texts in three of the five surviving late medieval Welsh witnesses of the Eagle: alongside the Prophetiae Merlini, both the Latin and Welsh texts of Proffwydoliaeth yr Eryr/Prophetiae Aquilae are found in NLW, Peniarth MS 47 ii, and the Welsh in both National Library of Wales, Peniarth 50 and Peniarth 16 (Parry 1930, xiv; Roberts 1977, 25; Jones 2013, 242-47). The two also appear as accompaniments in early modern 
collections of Welsh political prophecy (e.g., National Library of Wales, Mostyn 133, for which see Evans 1898-1910, II, 104).

In their insular manuscript context more broadly, the Prophetiae Merlini and Prophetia Merlini Silvestris are familiar companion pieces, and follow continuously in five of the seventeen (predominantly English) medieval manuscripts surveyed for this article; they follow the Historia in three manuscripts, while four other manuscripts contain the Historia or Prophetiae elsewhere (see Table 1; for additional examples, see Crick 1991, 65-66).

\section{Merlin Silvester and the Eagle}

The earliest title given to the collection was the Prophecies of Merlin Silvester. This prophetic authority first appears in Latin literature in the writings of Geoffrey of Monmouth: the Merlin of the woods, the titular character of Geoffrey's Vita Merlini, located in the Caledonian Forest in the sixth century, whose prophecies contain the account of Arthur's departure to the island of Avalon (Parry 1925; Clarke 1973). This Merlin is both geographically and temporally distinct from the fifth-century Merlin Ambrosius of Geoffrey's earlier Prophetiae Merlini, prophet to Vortigern, who is based on the child-prophet Ambrosius who appears in the Historia Brittonum -although in the Vita, Geoffrey emphasised the unity of the two. Geoffrey is understood to have been inspired in the Vita Merlini by Welsh legends of the northern British prophetic wild man of the type found in the prophecies of the Black Book of Carmarthen, which can be traced back to at least as early as the eleventh century. This figure came to be associated with the name of the prophet Myrddin, the Welsh Merlin-original, although the precise period of this conflation remains controversial (Jarman 1960, 2008; Padel 2006; Tolstoy 2008).

Through Geoffrey, the concept of the British prophetic wild man was widely known in both England and France. In the mid-twelfth century, the Merlin of Geoffrey's Vita appears as 'Merlin Silvester' in library catalogues from northern France differentiating the Historia, or the Prophetiae, from the Vita, and this distinction appears to have been of broader English utility also (Dumville 1985, 34; Jensen 1989, 47). This may be how Gerald of Wales came by the name Merlin Silvester, which he uses to establish a similar distinction between Merlin Ambrosius and the Merlin of the Vita Merlini-for Gerald, a second Merlin. In the Itinerarium, Gerald gives this second Merlin, his Silvester, a short biography - a wild man of the woods, whose prophetic abilities are associated with battle madness (Thorpe 1978, 192). Alongside the Vita, Gerald appears to have been acquainted with a Welsh form of the wild man legend similar to that known to Geoffrey, for in the Expugnatio he writes of the prophecies of the northern Merlin as known only partially in England but in fuller form in 'rustic' Welsh ('Britannicam barbariem'), and ripe for Latin translation and English dissemination-as he understands Geoffrey's Prophetiae Merlini to have done for the prophecies of Merlin Ambrosius (Scott and Martin 1978, 252-53).

By the thirteenth century, the use of the name Merlin Silvester suggests a selfconscious Galfridian, and/or a Giraldian, source debt. The Prophecies of Merlin 
Silvester also circulated under another name, similarly suggesting a cultivated Galfridian relationship. In a number of manuscripts, the collection is ascribed to another authority, an eagle, and the Prophecy of the Eagle is the title under which a good deal of previous critical work on the collection has been published. The first attributing of the collection to an eagle is found in English and Welsh-border witnesses from the fourteenth century onwards. Alongside these witnesses, this ascription is also given in the Welsh Brut versions of the prophecy. The prophecies are interpolated as those of the eagle who spoke to the British king Lud Hudibras while the city walls were built at Shaftsbury, and whose words Geoffrey disdained to repeat in Historia II (Parry 1937, 30-33). The precise origins of the concept of the prophetic eagle remain obscure, although the talking eagle of Sestos, which appears in Pliny's Natural History, has been suggested as a possible influence (Crick 1991, 65), as have the sixty talking eagles of Loch Lomond recorded as a marvel in the Historia Brittonum (Sutton and Visser-Fuchs 1989, 293). For Geoffrey, it may have also offered an intersection with the twelfth-century Welsh poem preserved in the Book of Taliesin, Ymddiddan Arthur a'r Eryr, where Arthur converses with his nephew Eliwlad, who has been transformed into an eagle, although this text is instructional rather than prophetic (Williams 1925). Most importantly, through this attribution, the prophecies were placed in an explicitly Galfridian context, filling a lacuna in the Historia. The relationship of the collection to the Galfridian tradition is strongly in evidence in its uses in both England and Wales, and the authorities to which it was ascribed, Merlin Silvester and the Eagle, demonstrate its status as a part of the Galfridian Apocrypha.

\section{'Sicut rubeum' and the Galfridian Tradition}

We come now to the part of the collection most commonly understood to be of Welsh origin: the passages of 'Sicut rubeum' which correspond to prophecies which appear in the first recension of Gerald of Wales's Expugnatio Hibernica, a text originally entitled 'Vaticinalis Historia', concerned with the realisation of ancient prophecies in contemporary history (Scott and Martin 1978, 1xi-1xxii; Putter 2009, 97-98). In order to understand the relationship between 'Sicut rubeum' and Gerald's prophecies, we must first look to the influence of Geoffrey's Prophetiae.

The Prophetiae Merlini provided the primary model for the composition and uses of political prophecy in late twelfth and thirteenth-century England, not least in terms of its defining interest in high political actors and affairs. The Prophetiae combines retrospective and contemporary historical commentary with genuinely futurist material, presenting a vision of insular history from the coming of the Saxons to the Normans, and beyond. It reads as a type of king list, moving from the historical to the genuinely futurist. The Prophetiae opens with the prophecies of Merlin Ambrosius pertaining to the coming of the Saxons, depicted as a battle for territorial control between the white dragon of the Saxons and the red of the Britons. This is a reworking of the Omen of the Dragons of the Historia Brittonum, which forecasts the subjugation of the red dragon of the Britons by the white of the Saxons, prior to the eventual victory of the red (Morris 1980, §42). The original Omen has 
been understood to be representative of a contemporary tradition of Welsh vernacular prophecy, translated into Latin (Sims-Williams 2008, 35). It was certainly an important motif in subsequent Welsh political literature, and is referred to in the context of Welsh translations of the Prophetiae Merlini as Y Broffwydoliaeth Fawr (The Great Prophecy) (Evans 1966-68; Jones 2013, 120-21). However, in the context of the Prophetiae Merlini, Geoffrey's Omen functions in relation to a very different political agenda. Mastery passes not back to the Britons but to a new people, clad in wood and iron (1. 72), who cross the sea from Normandy to lay claim to Britain. Geoffrey followed this account of the Norman Conquest with a brief ciphered account of events from the reigns of William I, William Rufus, and Henry I, before moving into a lengthy, genuinely futurist, and highly pessimistic, depiction of the future of the island, its rulers, and its peoples.

Geoffrey's Omen is the basis of the opening allusion in 'Sicut rubeum'. In a Galfridian-inspired re-imagining of the Omen, the prophecy opens with the displacement of the red dragon of the Britons by the white of the Saxons, displaced in turn by the dark dragon of Normandy:

Sicut rubeum draconem albus expellet sic niueum eiciet tenebrosus. Draco teterrimus \& terribilis aduolabit qui oris sui flatu igne flammigero insulam totam inficiendo concremabit.

(Just as the white dragon expelled the red, so the dark [dragon] will throw out the white one. Terrible and most foul, the dragon will fly towards, and will burn up, the entire island breathing flaming, corrupting fire from his mouth.) ${ }^{3}$

This opening sentence is a prologue to Norman rule, and a king list follows, spanning the reign of the dark dragon (William I), a crusading ram (Robert Curthose), and a king of poisonous aspect (the unpopular William Rufus). The account of the last named's death, a petty king struck by lightning, perhaps owes something to Geoffrey's allusion to the death of William Rufus as a suffocation by the arrow of envy (Prophetiae, 11. 76-77; printed in Wright and Reeve 2007). After this, the lion of justice (Henry I) is introduced, an identification inspired by Geoffrey of Monmouth's use of the epithet as a cipher for the king in Prophetiae, 1. 80. The lion is followed by a crab whose reign brings war and suffering (Stephen) and, finally, by a tusked boar, a heroic and Arthurian signifier in Prophetiae, 11. 39-42, used to represent Henry II in later Latin prophetic texts, most notably in the Prophetia Merlini of John of Cornwall (Curley 1982, 246-47). Some of these figures are taken directly from Geoffrey-and we certainly see his influence in the use of animal ciphers, which were the basis of his distinctive prophetic style-while others are variations on this theme. This system of prophetic representation, tracing the kings who ruled after the Conquest, was recognisable to the first generations of the prophecy's readers. The (contemporary, main text) annotations which accompany the prophecy in Cambridge University Library, Ff. i. 27 (fol. 497r) and Cambridge, Corpus Christi College 404 (fols 96v-97r) attest to the fundamental

\footnotetext{
${ }^{3}$ I quote from the edition of the text printed as an appendix to Parry (1937), with minor emendation. My punctuation. The translation is my own.
} 
intelligibility of this prophetic technique. The annotations are here set against the passages they were intended to gloss (annotations are given in bold):

draco teterrimus et terribilis

delicati uelleris aries

regulus venenati aspect $u s$

leo fulminato

cancer marinus succedet leoni

Dentatus aper cancro succedet

ex apri libidine catuli nascent

donec albania peregrinatis

$\ldots$ in occidentem irruens hibernie robora...

cum matris in utero patrem...

Descendens leonis ex semen linx...

\author{
Williamus i \\ Curthoose \\ Williamus ii rufus \\ Henricus i \\ Stephanus \\ Henricus ii \\ filii henricus ii \\ qd ferit in captoram William \\ rege scotie \\ de conquestu hibernie \\ de morte sancta Thomas ${ }^{4}$ \\ Henricus iii
}

Similar annotations have also been noted in Leiden, University Library, VLF 77 (Schulz 1854, 464-65).

The same process of historical analysis is at work in many of the prophecies ascribed to Merlin Silvester, and his Irish counterpart, St Moling, that Gerald applies to contemporary affairs in the first recension of the Expugnatio, and it is in relation to these same applications that the 'Sicut rubeum'-author incorporated Gerald's prophetic material in his king list. The following sequence combines repetitions of Gerald's prophecies, concerned (in order) with: the rebellion of Henry's sons, led by Henry the Young King; the death of Thomas Becket; English victory in Scotland; and Henry II's conquest of Ireland and subjugation of the Irish kings:

Patris iniuria prosternet filios quorum primus regni culmen ascendens subito tamen \& quasi flos uernus citra fructum emarescet. Ex delicto genitoris geniti delinquent in genitorem \& precedens delictum fiet causa sequentium delictorum. Filii insurgent in parentem \& ob sceleris uindictam in uentrem uiscera coniurabunt. In uirum sanguinis sanguis insurget \& desperabilis fiet afflictio. Donec Albania peregrinantis fleuerit penitentiam. Veniet ab aurora turbo ualidus qui in occidentem irruens hybernie robora cuncta subuertet; coram ipso precedent principes \& fucato sub federe pacis amorem consequentur. Dolor \& gaudium conuertetur cum matris in utero patrem trucidabunt.

(The wrongs of the father will lay low the sons, of whom the first climbs to the summit of the kingdom, and yet suddenly will wither away like a spring flower before fruit is produced. Because of the sin of the father the sons offend against the father and the preceding sin will be the cause of the following sin. The sons will rise up against the parent and for vengeance of a crime in the belly the entrails will conspire. Blood will rise up against man of blood and the suffering will be terrible. Then Scotland will cry for the penitence of a pilgrim.

${ }^{4}$ CUL, Ff. i. 27 only. 
A powerful whirlwind from the east rushing to the west will overthrow all the oaks of Ireland; princes will go before him and they will follow love under a feigned treaty of peace. Sorrow will be turned to joy when they will slaughter the father in the womb of the mother.)

The allusion to the sins of the father, the rising of the sons against the parent, and the entrails in the belly, are quoted by Gerald as a prophecy of the princes' rebellion, understood as punishment of Henry for the murder of Thomas Becket (Scott and Martin 1978, 124-25). The murder of the father (a churchman) in the womb of the mother (the church) is, for Gerald, a prophecy of the death of Becket, as is surely meant here (Scott and Martin 1978, 74-75). The 'Sicut rubeum'-author also makes use of the prophecy which concludes Gerald's account of Henry's contrition and pilgrimage to Canterbury in 1174 , which was followed by an unexpected victory for English royal forces in Scotland that came to be attributed to the intercession of the deceased archbishop: Henry is the penitential pilgrim of this passage (Scott and Martin 1978, 122-25). This was a relatively pervasive contemporary perception (Clanchy 1998, 92-93). The author also borrows Gerald's prophecy of Henry's 1170 conquest of Ireland. Henry appears in the Expugnatio, in a prophecy ascribed to Moling, as a whirlwind in the west, who overthrows the oaks of 'Herimon', understood by Gerald to be the first legendary king of the Irish (Scott and Martin 1978, 93-96). The penultimate allusion here is also ascribed by Gerald to Moling, the feigned peace treaty, in relation to Henry's Irish conquests (Scott and Martin 1978, 96-97).

Most of these prophecies are presented by Gerald as counterparts to, and some even read as variations upon, material from the Prophetiae. One of the most notable of these is Gerald's uses of Geoffrey's prophecy of the sixth king who conquers Ireland. Like a number of his contemporaries, Gerald identified Henry with the imperial Sextus of Prophetiae, 11. 99-105, a British high king who after a troubled youth unites the five provinces of Ireland and restores the holy places of the saints. Citing Merlin Ambrosius, Gerald writes of Henry's securing of the homage of the Irish kings at Osraige: 'Quinque porciones in unum redigentur, et sextus Hiberniae moenia subvertet' ('The five parts will be reduced to one, and the sixth will overthrow the walls of Ireland') (Scott and Martin 1978, 96-97). Gerald's prophecy of the whirlwind which overthrows Ireland is one of many treatments of the Sextus-theme, and is quoted alongside its Galfridian counterpart. The term Sextus functioned as a prophetic cipher rather than a direct numerical designation (Henry was the fifth king after the conquest) — it was part of a body of related ideas belonging to a distinctively Galfridian conceptualisation of English royal history.

Both Gerald's prophecies and 'Sicut rubeum' correspond to the use of the Prophetiae Merlini as a mode of political commentary in the generations following Geoffrey. E. K. Chambers long ago argued that Gerald was acquainted with a Latin commentary on the Prophetiae, produced in Wales, which formed the basis of his prophecies in the Expugnatio (Chambers 1927, 99). However, we need not look to Wales for precedent for such an undertaking. Although a number of additions to the Prophetiae in John of Cornwall's mid-twelfth-century Latin commentary appear to be drawn from a Welsh context (Curley 1982) and, certainly, there is an important 
Welsh reception history for the Prophetiae, there is no reason to associate the composition of 'Sicut rubeum' with this particular movement. Commentaries on the Prophetiae concerned with contemporary politics date from the text's very earliest reception history, beginning with Orderic Vitalis in the 1130s, who in his Historia Ecclesiastica, working from an early copy of the Prophetiae in circulation at the northern French monastery of Bec, identified references in Geoffrey's text to the Norman Conquest and the sons of William the Conqueror (Chibnall 1978, VI, 38687). This contemporary onus is a feature of commentaries on the Prophetiae, which continued to circulate throughout the later twelfth century and into the thirteenth, concerned with great events of the age, including the relationship between Henry II and Thomas Becket (Southern 1972, 168-69; Crick 1992).

The prophetic history of 'Sicut rubeum' extends beyond the scope of Gerald's prophecies, leading to an account of the loss of Normandy in 1204, early in the reign of John. This was regarded by contemporaries as a consequence of John's own friendly engagements with the French king in his attempts to unseat his brother, Richard I, during the $1190 \mathrm{~s}$, and was widely understood as a sign of the decline of the Plantagenet imperium by consequence not only of political inanity but of a broader moral failing. John was the subject of considerable antipathy for his domestic policies also, which assumed prophetic form in the Merlinian prophecy incorporated in the Anglo-Norman romance, Fouke le Fitz Waryn, concerned with the infringements of the king upon the property rights of the Fitz Waryn family, in the Welsh March. John appears here as a grasping leopard, who is to be defeated by a skilful wolf, Fouke III (Hathaway et al. 1975, 11. 19-36; discussed by Flood 2016, 58-65). The treatment of John in 'Sicut rubeum' is much in this vein. We read: 'Descendens leonis ex semine linx succedet, cuius acumen ferrea simul \& saxea robora transpenetrabit, huius aggressu utramque insulam relinquet neustria' (A lynx will succeed, descending from the seed of the lion, whose sharpness will penetrate with the strength of iron and stone simultaneously, and from this assault Normandy will lose both its islands). This is another Galfridian cipher, taken from Prophetiae, 11. 105-07, a prophecy of the lynx who destroys his own people, and on whose account the Normans (or rather, their descendants) lose their cross-channel empire. The association of John with the lynx was commonplace during this period. It rested on the identification of Henry II with the Sextus of Prophetiae, 11. 99-100, who precedes the lynx (Taylor 1911, 50-51; Crick 1992, 368). The prophecy of the lynx might also have been particularly appropriately applied to the events of 1213 , when the Pope accepted England and the Lordship of Ireland as papal fiefs (an alternative meaning for the two islands to which the prophecy refers). The prophecy was also open to trans-historical reapplication: from the mid-thirteenth century, the lynx was identified as Henry III, in whose reign the Treaty of Paris (1259) made final the losses of John's reign (Eckhardt 1982, 28; Sutton and Visser-Fuchs 1990, 356-57). This is a feature of the CUL Ff. i. 5 and CCCC 404 annotations (above).

The conditions of the 1204 loss are also alluded to in 'Sicut rubeum'. A prophecy of French conquest follows from the accession of the lynx: '\& miro mutationis modo gladius a sceptro separabitur' (and by a marvellous manner of change, the sword will be separated from the sceptre). The separation of sceptre and sword is given as a prophecy of the separation of England and Normandy in Ralph of 
Coggeshall's Chronicon anglicanum (c. 1227) (Stevenson 1875, 146), where it is quoted as a Merlinian prophecy of the losses of John's reign. This may well be a testament to the early circulation of 'Sicut rubeum', or component material, and the resonance of this phrase. In 'Sicut rubeum', the separation is associated with John's dealings with the French king, and earlier betrayal of Richard: 'propter fratrum discordiam regnabit ex transuerso ueniens' (because of discord of brothers one coming from the other side will reign). The arrival of one from the other side probably originally functioned as a presentiment of the invasion of Philip Augustus (from across the English Channel), potentially placing the composition of the prophecy in 1212-13, when in France advanced preparations for the invasion of England were afoot. This ambition was briefly realised in 1216, when Philip's son Louis reached as far as London. The absence of this specific detail from the text suggests that it was probably composed prior to 1216 .

\section{The Here Prophecy}

There is a second element of 'Sicut rubeum' which has, more recently, been understood to suggest a Welsh source-relationship: the author's incorporation of a short late twelfth-century prophecy known as the 'Here Prophecy' (Coote 2000, 62). It is first found in Gesta Regis Henrici Secundi, once attributed to Benedict of Peterborough but now thought to be the work of Roger of Hoveden, writing in the late twelfth century (Stubbs 1867, II, 139):

Pan pu seches in here, hert yreret

pan sulen Hengles in pre be ydeled

pat han sale into Hyrlande alto ladewaya

pat hoper into Poile mid pride bileve

pe thirde in hayre haughen hert alle ydreghe.

(When you see a hart raised in Here, then shall the English be divided into three: the one [part] shall into Ireland ?all lead away; the other into Apulia with pride, without delay; the third in their own heart all sorrow endure) ${ }^{5}$

Another Middle English version of the prophecy is found in fragmentary form in the copy of 'Sicut rubeum' in the early-mid-thirteenth-century Cambridge, Corpus Christi College 313. Here the Latin passage is annotated with the following Middle English fragment:

...d sal into puille and riche y wurpe oper sal into hyre[1] and and zedi y wu[r]pe pridde sal in engle al uor purpe be rich

be wealthy

perish

(fol. 107r; my transcription)

Unfortunately, too little is known of the provenance of this manuscript to allow for further comment on the circulation of the Middle English text, although it is possible that, like Roger, the copyist may have been in a religious order. Michael

\footnotetext{
${ }^{5}$ Editorial yoghs are corrected as thorns. This is a modified translation from that offered by Stubbs.
} 
Richter has certainly noted the uses of English at monastic houses during this period (Richter 1979).

Roger of Hoveden interprets the prophecy in relation to the raising of the sign of the hare by Ranulfo filio Stephani in a house in Here granted to him by Henry II in 1190 or '91. The son of a chamberlain of Henry II, Ralph was a courtier in the service of Henry and later Richard. Through the patronage of both kings he built up a modest territorial base in Gloucestershire, later extended into Derbyshire (Boorman 2004). A case has more recently been made for an earlier Devonshire provenance for the verses, through a suggested association with the Fitz Stephen family, who owned a property named Harford, and it has been speculated that the prophecy might be a translation from Cornish or Welsh circulating in Devonshire (Coote 2000, 62). However, on such a slight sample a south-western provenance cannot be assumed with any certainty, and there are no obvious indications of a Welsh or Cornish-language source. In fact, the Here-prophecy is of immense scholarly significance as one of the earliest political prophecies composed in Middle English: conceived in relation not to a Welsh or Cornish source, but a Latin tradition of Galfridian political prophecy active in England.

The prophecy is concerned with the division of 'Hengles', the English, into three parts-an allusion to population dispersal (the final line makes use of the third person plural possessive 'hayre'), although this is probably rooted in a concern with the movements of the kings of England. As Hales noted, the reference to Ireland reads as an allusion to Henry II's campaigns, and Apulia to Richard I's involvement in the Third Crusade (Hales 1893, 55-61). The third part, which suffers in England, is presumably a reference to the perceived vulnerability of English subjects in the absence of their king. It probably puns on the word 'here', both as a location, and as an early Middle English noun, meaning 'foreign invasion' (as it appears in the roughly contemporary Lazamon's Brut, see $M E D$, 'here, n.1'). In its reworking in 'Sicut rubeum', the dispersal of the English is conflated with Prophetiae, 11. 74-75, the exile of the seed of the white dragon (the Saxons) at the beginning of the age of the Normans. Alignment of the prophecy with Galfridian allusions appears to have been an integral part of the translation process (from English into Latin). It is also contemporised: the modified 'Here Prophecy' appears in 'Sicut rubeum' in the broader context of the French king's invasion, and functions as a comment on contemporary foreign policy:

In ultimis diebus albi draconis semen eius triphariam spargetur. Pars in apuliam tendens orientali gaza locupletabitur. Pars in hyberniam descendens occidua temperie delectabitur. Pars uero tercia in patria permanens uilis \& uacua reperietur.

(In the last days of the white dragon its seed will be scattered into three parts. Part encamps in Apulia and will take pleasure in eastern treasure. Part descends into Ireland and will delight in a westerly climate. However, the third part remains in the fatherland and will be found to be worthless and empty.)

In the broader context of the king-list of 'Sicut rubeum', the empty third part reads as a reference to the loss of Normandy under John, juxtaposed with the conquests of 
the reigns of John's brother and father. Certainly, this is consistent with the earlier depiction of John as the lynx. ${ }^{6}$

\section{Conclusion}

The Prophecies of Merlin Silvester are a paradigmatic example of the uses of prophecy as historical writing in thirteenth-century England. The collection provides a ciphered historical overview, pertinent to the political situation of the 1210s. The king-list of 'Sicut rubeum' locates events of the reign of John in a long historical context. In both its influences and its reception history, this text, like the collection as a whole, has implications for the understanding of prophetic-historical engagement in England, and its, by this period, remote rather than immediate, relationship to Welsh influences. The tradition with which the prophecies were aligned was part of the cultural mainstream of Latinate prophetic composition in England. 'Sicut rubeum' contains a number of clear historical-political ciphers, rooted in familiar principles of Latin prophetic composition, some of which possess remote Welsh source relationships through Geoffrey of Monmouth, but emerge in this period fully naturalised as part of an Anglo-centric engagement with prophecy as a mode of historical commentary.

Acknowledgements With thanks to Erich Poppe and Megan Cavell for their comments on this article; and Venetia Bridges for her assistance with Latin translation. All mistakes that remain are my own. I would also like to express my thanks to the Alexander von Humboldt Foundation for a postdoctoral fellowship, during which time I completed the research for this article. Thanks are also due to the British Library, the National Library of Wales, Cambridge University Library, Lambeth Palace Library, and the master and fellows of Corpus Christi College, Cambridge and St John's College, Cambridge.

Open Access This article is distributed under the terms of the Creative Commons Attribution 4.0 International License (http://creativecommons.org/licenses/by/4.0/), which permits unrestricted use, distribution, and reproduction in any medium, provided you give appropriate credit to the original author (s) and the source, provide a link to the Creative Commons license, and indicate if changes were made.

\section{References}

\section{Primary}

Chibnall, M. (Ed.). (1978). Orderic Vitalis: The ecclesiastical history (Vol. 6). Oxford: Clarendon Press. Clarke, B. (Ed.). (1973). The life of Merlin. Cardiff: University of Wales Press.

Curley, M. J. (1982). A new edition of John of Cornwall's Prophetia Merlini. Speculum, 57, 217-249.

Eckhardt, C. (Ed.). (1982). Prophetia Merlini of Geoffrey of Monmouth: A fifteenth-century English commentary. Cambridge, MA: Medieval Academy of America.

Evans, J. G. (Ed.). (1891). The poetry in the Red Book of Hergest. Llanbedrog.

\footnotetext{
${ }^{6}$ Coote notes this comparison, and suggests that the empty part may be John himself. (Coote 2000, 63). However, the prophecy appears to use this term to allude to a territory, and there is no precedent for its use in application to a person.
} 
Evans, R. W. (1966-68). 'Y Proffwydoliaeth Fawr' a'r 'Broffwydoliaeth Fer'. Bulletin of the Board of Celtic Studies, 22, 119-121.

Hathaway, E. J., Ricketts, P. A., Robson, A., \& Wilshere, A. D. (Eds.). (1975). Fouke le Fitz Waryn. Oxford: Oxford University Press.

Morris, J. (Ed.). (1980). Nennius: British history and the Welsh annals. London: Phillimore.

Parry, J. J. (Ed.) (1925). The Vita Merlini. Urbana.

Parry, J. J. (Ed.). (1937). Brut y Brenhinedd: Cotton Cleopatra version. Cambridge, MA.

Roberts, B. F. (Ed.). (1971). Brut y Brenhinedd: Llanstephan MS. 1 version. Dublin: Dublin Institute for Advanced Studies.

Schulz, A. (Ed.). (1854). Gottfried's von Monmouth Historia Regum Britannice. Eduard Anton: Halle.

Scott, A. B., \& Martin, F. X. (Eds.). (1978). Giraldus Cambrensis: Expugnatis Hibernica: The conquest of Ireland. Dublin: Irish Royal Academy.

Stevenson, J. (Ed.). (1875). Radulphi de Coggeshall: Chronicon Anglicanum., Rolls Series 66 London: Longman.

Stubbs, W. (Ed.). (1867). Gesta Regis Henrici Secundi Benedicti Abbatis: The chronicle of the reigns of Henry II and Richard I AD 1169-92 (Vol. 2)., Rolls Series 49 London: Longman.

Thorpe, L. (Ed.). (1978). The journey through Wales and the description of Wales. Harmondsworth: Penguin.

Williams, I. (1925). Ymddiddan Arthur a'r Eryr. Bulletin of the Board of Celtic Studies, 2, 269-286.

Wright, N., \& Reeve, M. D. (Eds.). (2007). Geoffrey of Monmouth: The history of the kings of Britain. Woodbridge: Boydell and Brewer.

\section{Secondary}

Ashe, L. (2007). Fiction and history in England, 1066-1220. Oxford: Oxford University Press.

Boorman, J. (2004). Ralph fitz Stephen (d.1202). Oxford dictionary of national biography. Oxford: Oxford University Press. http://www.oxforddnb.com/view/article/48113. Accessed March 16, 2017.

British Museum. (1834). Catalogue of manuscripts in the British Museum. New series, Vol. 1, Part 1: The Arundel manuscripts. London: Trustees of the British Museum.

Chambers, E. K. (1927). Arthur of Britain. London: Sedgwick and Jackson.

Clanchy, M. (1998). England and its rulers 1066-1272. London: Wiley.

Coote, L. A. (2000). Prophecy and public affairs in later medieval England. Woodbridge: York Medieval Press.

Crick, J. (1989). Historia Regum Britanniae of Geoffrey of Monmouth. III. A summary catalogue of the manuscripts. Cambridge: D. S. Brewer.

Crick, J. (1991). The Historia Regum Britannie of Geoffrey of Monmouth. IV: Dissemination and reception in the later Middle Ages. Cambridge: D. S. Brewer.

Crick, J. (1992). Geoffrey of Monmouth, prophecy and history. Journal of Medieval History, 18, 357-371.

Dumville, D. (1985). An early text of Geoffrey of Monmouth's Historia Regum Britanniae and the circulation of some Latin histories in twelfth-century Normandy. In R. Barber (Ed.), Arthurian literature IV (pp. 1-36). Cambridge: D. S. Brewer.

Evans, J. G. (1898-1910). Report of manuscripts in the Welsh Language (2 Vols.). London: Historical Manuscript Commission.

Flood, V. (2016). Prophecy, politics and place in Medieval England: From Geoffrey of Monmouth to Thomas of Erceldoune. Cambridge: D. S. Brewer.

Given-Wilson, C. (2003). Chronicles of the Mortimer family, c.1250-1450. In R. Eales \& S. Tyas (Eds.), Family and dynasty in late medieval England: Proceedings of the 1997 Harlaxton symposium (pp. 67-86). Shaun Tyas: Donington.

Hales, J. W. (1893). Folia Litteraria: Essays and notes on English literature. London: Seeley and Co.

James, M. R. (1911-12). A descriptive catalogue of the manuscripts in the library of Corpus Christi College, Cambridge (2 Vols.). Cambridge: Cambridge University Press.

James, M. R. (1913). Descriptive catalogue of the manuscripts of the library of St John's College, Cambridge. Cambridge: Cambridge University Press.

Jarman, A. O. H. (1960). The legend of Merlin. Cardiff: University of Wales Press.

Jarman, A. O. H. (2008). The Merlin legend and the Welsh tradition of prophecy. In A. O. H. Jarman, B. F. Roberts, \& R. Bromwich (Eds.), The arthur of the Welsh: The Arthurian legend in medieval Welsh literature (pp. 117-145). Cardiff: University of Wales Press. 
Jensen, S. (1989). Merlin: Ambrosius and Silvester. In G. Barnes (Ed.), Words and wordsmiths: A volume for H. L. Rogers (pp. 45-48). Sydney: Department of English, University of Sydney.

Jones, A. L. (2013). Darogan: Prophecy, lament and absent heroes in medieval Welsh literature. Cardiff: University of Wales Press.

Ker, N. K. (Ed.). (1964). Medieval libraries of Great Britain: A list of surviving books. London: Royal Historical Society.

Macray, W. D. (1883). Catalogi codicum manuscriptorum Bibliothecae Bodleinae pars nona, codices a viro clarisimo Kenelm Digby, Eq. Aur, anno 1634 donatos, complectens: adiecto indice nominum et rerum. Oxford: Oxford University Press.

McCauley, B. L. (1993). Giraldus 'Silvester' of Wales and his Prophetic History of Ireland: Merlin's role in the Expugnatio Hibernica. Quondam et Futurus, 3, 41-62.

Padel, O. (2006). Geoffrey of Monmouth and the development of the Merlin legend. Cambrian Medieval Celtic Studies, 51, 37-65.

Parry, J. J. (1930). The Welsh texts of Geoffrey of Monmouth's Historia. Speculum, 5, 424-431.

Phillips, J. R. S. (1986). Edward II and the prophets. In W. M. Ormrod (Ed.), England in the fourteenth century: Proceedings of the 1985 Harlaxton symposium (pp. 189-201). Woodbridge: Boydell Press.

Planta, J. (1802). Catalogue of the manuscripts in the Cottonian Library, deposited in the British Museum. London: The British Museum.

Putter, A. (2009). Gerald of Wales and the prophet Merlin. In C. P. Lewis (Ed.), Anglo-Norman studies 31: Proceedings of the Battle conference 2008 (pp. 90-103). Woodbridge: Boydell Press.

Reiss, E. (1968-69). The Welsh versions of Geoffrey of Monmouth's Historia. Welsh History Review, 4, 97-127.

Richter, M. (1979). Sprache und Gesellschaft im Mittelalter: Untersuchungen zur mündlichen Kommunikation in England von der Mitte des XI. bis zum Beginn des XIV. Jahrhunderts. Stuttgart: Anton Hiersemann.

Robbins, R. H. (1975). Poems dealing with contemporary conditions. In A. E. Hartung (Ed.), A manual of the writings in Middle English, 1050-1500 (Vol. 5, pp. 1385-1536). New Haven, CT: Academy of Arts and Sciences.

Roberts, B. F. (1977). Copiau Cymraeg o Prophetiae Merlini. Cylchgrawn Llyfrgell Genedlaethol Cymru, 20, 14-39.

Roberts, B. F. (2008). Geoffrey of Monmouth, Historia Regum Britanniae and Brut y Brenhinedd', Arthur of the Welsh, pp. 97-116.

Schofield, W. H. (1906). English literature from the Norman Conquest to Chaucer. London: Macmillan.

Sims-Williams, P. (2008). The early Welsh Arthurian poems. The Arthur of the Welsh, 33-71.

Southern, R. W. (1972). Aspects of the European tradition of historical writing: 3. Prophecy as history. Transactions of the Royal Historical Society, 22, 159-180.

Sutton, A., \& Visser-Fuchs, L. (1989). Richard III's books: VIII. Geoffrey of Monmouth's Historia Regum Britanniae with The Prophecy of the Eagle: 2. Prophecy and commentary. The Ricardian, 8 , 290-304.

Sutton, A., \& Visser-Fuchs, L. (1990). Richard III's books: VIII. Geoffrey of Monmouth's Historia Regum Britanniae with The Prophecy of the Eagle and commentary: 2. The prophecy and commentary (continued). The Ricardian, 8, 351-362.

Sutton, A., \& Visser-Fuchs, L. (1992). The dark dragon of the Normans. Quondam et Futurus, 2, 1-18. Taylor, R. (1911). The political prophecy in England. New York: Columbia University Press.

Thomas, H. M. (2003). The English and the Normans: Ethnic hostility, assimilation, and identity, 1066-c.1220. Oxford: Oxford University Press.

Tolstoy, N. (2008). Geoffrey of Monmouth and the Merlin legend. In K. Busby \& R. Dalrymple (Eds.), Arthurian Literature XXII (pp. 1-42). Cambridge: D. S. Brewer.

Walker, D. (1984). Cultural survival in an age of conquest. In R. R. Davies (Ed.), Welsh society and nationhood: Historical essays presented to Glanmor Williams (pp. 35-50). Cardiff: University of Wales Press.

Ward, H. L. D. (1883-1910). Catalogue of romances in the Department of Manuscripts in the British Museum (2 Vols.). London: British Museum.

Warner, G. F., \& Gilson, J. P. (1921). Catalogue of western manuscripts in the old Royal and King's Collections (4 Vols.). London: British Museum.

Wells, J. E. (1926). A manual of the writings in Middle English, 1050-1400. New Haven, CT: Academy of Arts and Sciences. 